\title{
Analysis of Honey Value Chain and Marketing System: The Case of Smallholder Beekeepers in Negele Arsi District of Oromia, Ethiopia
}

\author{
Taye Beyene \\ Oromia Agricultural Research Institute, Adami Tulu Agricultural Research Center, Zeway, Ethiopia
}

\section{Email address:}

tayebeye@yahoo.co.uk

\section{To cite this article:}

Taye Beyene. Analysis of Honey Value Chain and Marketing System: The Case of Smallholder Beekeepers in Negele Arsi District of Oromia, Ethiopia. American Journal of Theoretical and Applied Business. Vol. 7, No. 3, 2021, pp. 54-64. doi: 10.11648/j.ajtab.20210703.11

Received: July 6, 2021; Accepted: July 21, 2021; Published: July 27, 2021

\begin{abstract}
The study was conducted in Negele Arsi district, West Arsi Zone, Oromia, Ethiopia to identify honey value chain actors, functions, services providers, major constraints and opportunities of beekeeping. Quantitative and qualitative data was collected by desk research, observations, survey and interview with different actors in the chain. The collected data were analyzed using descriptive statistics such as percentages, frequencies, mean and standard deviations using SPSS version 19 and Excel sheets. Whereas, the data collected through interview was analyzed using narration and interpretation. The value chain map was used to get the clear picture of the whole honey market chain and SWOT analysis tool was used to analysis the strength, weakness opportunity and threat of the beekeeping sector in Negele Arsi district. The study result showed that, the major value chain actors in the study district were producers, local collectors, wholesalers, retailers, local drink makers and final consumers of the product were the main chain actors, while Negele Arsi livestock development and fisher resource office, Adami Tulu Agricultural Research Center, IDE (International Development Enterprises) and SNV Ethiopia were the main chain supporters and service providers. Six main alter native market channels were identified for honey marketing and honey follows the six main routes from the point of its production to its consumption. The major constraints of beekeeping identified in the study district were inaccessibility to beekeeping equipments, inadequate of beekeeping knowledge and skills, shortage of bee forage, prevalence of honeybee pests and predators, lack of organized market channel, pesticides poisoning, lack of adequate extension services, honeybee colony absconding and migration and shortage of honeybee colony. Despite these, there are also opportunities such as availability of area closures, high demand for honey at national, regional and international market, presence of government and non-government organizations working on honey, the existence of conducive policy framework in apiculture sub-sector, existence of farmers with indigenous knowledge and skills who are interested to accept improved technologies, existence of reforestation plan and existence of different flowering plants are some of the opportunities for honey production and marketing by most of the producers. Therefore, efforts should be geared to promoting capacity building through training, promoting modern apiculture technologies, access extension service, access to financial support and market promotion and establishment of beekeepers cooperatives are recommended.
\end{abstract}

Keywords: Beekeeping, Value Chain, Honeybee, Marketing Channels

\section{Introduction}

Ethiopia has high potential for beekeeping as a climate is favorable for growing different vegetation and crops, which are good sources of nectars and pollen for honey bees. The diversified agro climatic conditions of the country create environmental conditions conducive for the growth of over 7000 species of flowering plants of which most are bee plants [7]. The ideal climatic conditions and diversity of floral resources allow the country to sustain around 10 million honeybees [6]. This is attributed to the qualitative nature of honey produced from different floral/nectar sources in different geographical regions.

Ethiopia, having the highest number of bee colonies and surplus honey sources of flora, Ethiopia is the leading honey producer in Africa and one of the ten largest honey-producing countries in the world the leading producer of honey [5]. The annual production amount of honey in Ethiopia is estimated 
to be 45,300 metric tons, thus shares $23.5 \%$ of Africa and $2.35 \%$ of world's honey production [2].

In Ethiopia beekeeping can play significant roles in poverty reduction, achieving sustainable development and conservation of natural resources. It is also important for the society as food, income generation for both domestic markets, export markets, as employment opportunity and other cultural aspects. Around two million farm households of the country are involved in beekeeping business using the traditional, intermediate and improved beehives [10]. The beekeeping subsector is also creating job opportunities in both rural and urban areas through organizing jobless urban and landless rural youth and women to involve in them in bee equipment production and beekeeping activities [4].

The apiculture sector in Ethiopia, however, is far from realizing its potential for earning foreign exchange, as well as generating income for smallholder beekeepers and other actors in the value chain. Less than $10 \%$ of the honey and wax potential have been tapped, and the commercialization of other high value bee products such as pollen, propolis and bee venom is non-existent [6].

Negele Arsi has great potential for beekeeping activities; due to the presence of diversified types of bee floras which used as pollen and nectar source for bees and suitable environmental conditions for bee colony and the production of honey. Negele Arsi district is believed to have diversified types of vegetation and cultivated crops and expected to be one of the areas that have considerable potential for beekeeping activities and honey production in west Arsi zone. The majority of household farmers in the area keep bees as a source of their main income from the honey sell as beekeeping doesn't need large area, big initial capital and fertile soil. It contributes $50 \%$ of the total income of the household [13]. Since honey and hive products are important source of food and income, it creates job opportunity and keeps the environment in balance through pollination. Although beekeeping practices are widely undertaken and have great economic value particularly in Negele Arsi district, so far there is no research study conducted on honey value chain in the study area. Furthermore in this area beekeepers are still suffering with input, production and market related problems. Hence, this study aimed at analysis of honey value chain in Negele Arsi district with the specific objectives of identifying honey value chain actors, functions, services providers and to identify the main factors affecting honey value chain and marketing system.

\section{Materials and Methodology}

\subsection{Study Area}

The study was carried out in Negele Arsi district, West Arsi Zone, Oromia Regional state, $225 \mathrm{~km}$ from Addis Ababa. Negele Arsi is situated at $7^{\circ} 19^{\prime}$ to $7^{\circ} 40^{\prime}$ North in latitude and $38^{\circ} 30^{\prime}$ to $38^{\circ} 53^{\prime}$ East longitudinally with an elevation of 500 to 2000 m.a.s.l (Google earth Map). The annual temperature is $10^{\circ} \mathrm{C}-25^{\circ} \mathrm{C}$. The average annual precipitation is $500 \mathrm{~mm}-1000$ mm. The crop-livestock mixed production system is the predominant system. Negele Arsi has erratic type of bimodal rainfall [7].

\subsection{Methods of Data Collection}

\subsubsection{Desk Research}

The secondary information was collected through the literature that were more focused on different research publications, articles, text books, reports from government institutions or international organizations, reports from beekeepers cooperative and company, MSc and $\mathrm{PhD}$ thesis and internet websites.

\subsubsection{Survey}

A survey was used to collect primary data by semistructured questionnaires which were designed for smallholders' beekeepers farmers. 36 smallholder beekeepers were randomly selected and information was explored.

\subsubsection{Case Study}

The interview was conducted using a checklist to collect data from randomly selected honey chain actors and supporters. A face to face interview was conducted with eight honey collectors, two wholesalers, four retailers, ten consumers, one government officer from district livestock office, one research center, two 'tej' house owners, one processor, one focal person of IDE and one focal person of SNV Ethiopia were interviewed. The interview was undertaken totally with 31 individuals to get information on how the existing honey market situation, constraints and opportunities of beekeeping in the study area.

\subsubsection{Data Analysis}

The data collected were analyzed using SPSS version 19 and Excel sheets. Descriptive statistics such as frequency, percentages, means and standard deviations were used to characterize honey value chain actors, functions and service providers and in analyzing socio-economic importance of honey value chain. Whereas, the data collected through interview was analyzed using narration and interpretation. The value chain map was used to get the clear picture of the whole honey market chain and SWOT analysis tool was used to analysis the strength, weakness opportunity and threat of the beekeeping sector in Negele Arsi district.

Table 1. List of different stakeholders interviewed during field study.

\begin{tabular}{llll}
\hline No. & Stakeholders & No. & Their role \\
\hline 1 & Beekeepers & 36 & Chain actors \\
2 & Honey collectors & 8 & Chain actors \\
3 & Wholesalers & 2 & Chain actors \\
4 & Retailers & 4 & Chain actors \\
5 & Consumers & 10 & Chain actors \\
6 & Own tej house & 2 & Chain actor \\
7 & Processor & 1 & Chain actor \\
8 & Governmental office & 2 & Chain supporter \\
9 & Non-governmental office & 2 & Supporters \\
Total & & 67 & \\
\hline
\end{tabular}




\section{Results and Discussion}

\subsection{Demographic Characteristics and Socio Economic of Sampled Respondents}

\subsubsection{Sex of the Respondents}

Of the total sample respondents $86.8 \%$ were male-headed and the remaining $13.2 \%$ were female headed household indicating that most of the sampled beekeeper households were male headed. These showed that apiculture business was mainly dominated by male gender in the study area. This could be due to the fear that women have for bee stings. Moreover, female cannot climb up big trees and hence discouraged to engage in the activity.

\subsubsection{Marital Status of the Respondents}

Regarding their marital status, majority of the respondents were married (73.7\%), followed by single (18.4\%) and divorced $(7.9 \%)$. The result of the majority being married indicated that apiculture business was dominated by responsible and matured people who could take decisions jointly with their spouses on their beekeeping business.

\subsubsection{Educational Status of the Respondents}

Regarding the level of education, major of the beekeepers $(44.7 \%)$ were illiterate who cannot read and write while the rest $(27.3 \%)$ literate. The remaining was in different level of literacy ranging from reading and writing skills to completion of college diploma and above (Table 2). The high literacy level of majority of the respondents would have implications on adoption of improved honey production techniques and consequently on their productivity because adoption of technology had been shown to have positive correlation with education attainment.

\subsubsection{Age of the Respondents}

The mean age of the sample households was 40 years (table 3). The result indicated that people in the most productive age are actively participated in beekeeping activities. Peoples in the aforementioned age do have the skill $\&$ strength to climbing big trees and uplift the hive to hang on branches of big trees.

Table 2. Household characteristics of beekeepers

\begin{tabular}{llll}
\hline Demographic variable & Response variable & $\mathbf{N}$ & $\mathbf{\%}$ \\
\hline Sex & Male & 33 & 86.8 \\
& Female & 5 & 13.2 \\
Educational level & Illiterate & 17 & 44.7 \\
& Read \& write & 8 & 21 \\
& Grade1-4 & 6 & 15.8 \\
& Grade 5-8 & 4 & 10.5 \\
& Grade 9-12 & 2 & 5.3 \\
Marital status & Diploma \& above & 1 & 2.6 \\
& Single & 7 & 18.4 \\
& Married & 28 & 73.7 \\
& Divorced & 3 & 7.9 \\
\hline
\end{tabular}

Table 3. Distribution of respondents' age and experience.

\begin{tabular}{llllll}
\hline Socio-economic indicators & Frequency & Minimum & Maximum & Mean & Std. Deviation \\
\hline Age (year) & 36 & 18.00 & 64 & 42.41 \\
Beekeeping experience (year) & 36 & 1.00 & 23 & 7.87 & 2.96 \\
\hline
\end{tabular}

\subsection{Value Chain Analysis of Honey}

Actors in Honey Value Chain and Their Roles

This study has identified different honey value chain actors and their roles in the study district from early production up to the final consumption. The major actors involved in honey value chain are input suppliers, beekeepers, local honey collectors, wholesalers, retailers, processors and consumers.

1) Input suppliers

Inputs in the honey value chain refer to the supply of hives, bee colonies, comb foundation, bee veils and other protective clothing, supplementary feed such as sugar and soya, technical know-how, packaging containers, and small equipment such as smokers, uncapping fork, hive stands, and honey extractors. It was found that the input suppliers do not confine themselves to one particular function, but rather take up several functions. In the study area there are governmental (District Office of Agriculture and Rural Development and Regional Research) and nongovernmental (SNV Ethiopia and IDE) organization with the aim of honey yield and quality improvement through provision of modern beekeeping inputs to the beekeepers. District livestock and regional research providing inputs like movable frame hive and equipments, trainings and free extension service with the help of expert's and developmental agents. Nongovernmental organizations such as SNV Ethiopia and IDE also help local beekeepers by providing modern beekeeping tools, equipments and training service for free for those households who have low income.

2) Beekeepers/producers

Considering the size and the scale of operations of the beekeepers, it is quite natural that the small producers tend to sell the honey in the local market as the prices offered are much higher. In the study area, smallholder honey producers producing honey using traditional, transitional and movable frame hives. These actors perform activities like foundation sheet preparation, honeybee colony transfer, provision of supplementary feeding, colony inspection, honey harvesting, filtering honey and transporting to market place. They sell their produce to local honey collectors, wholesalers, retailers and consumers.

\section{3) Local honey collectors}

Local honey collectors are the third link in the honey value chain in the study area and they are engaged in performing activities like buying from the beekeepers based on individual contacts and relationship from different localities and then resell it to retailers and consumers who come from 
different areas of the region at the district market center.

4) Wholesalers

The wholesalers are urban-based traders who collect honey from producers and local collectors in bulk and sell it to retailers or directly to consumers. The wholesalers either sell honey directly to the consumers after packaging, or they supply honey to retail shops and supermarkets after packaging. Some wholesalers give money (advance payment) for some collectors in the morning on the market day in order to bring for them the honey they bought from producers. These wholesalers will then sell the honey to the processors.

5) Retailers

Retailers are the value chain actors who buy the products from producers, local honey collectors and wholesalers in the form of semi processed or crude honey wholesalers and sell them to the final consumers. Furthermore they took finally processed honey from processors and reach on the hand consumers. The supermarkets, shopping centers, and grocery stores are the major retailers prevalent in the market.

\section{6) Processor}

Honey produced in the district by smallholder farmer was sold to the local honey collectors and wholesalers in crude forms. Then, they process and pack honey for export market by extracting liquid honey from the honey comb. The survey result revealed that only $16 \%$ of the beekeepers are supply their honey product to one honey processor and the rest of $84 \%$ of them just sell to any buyer at a time.

7) Consumers

The final chain actor is the consumer. The honey produced in the study area passes through different chain actors to reach on the hand of final consumers. There are two types of consumers who consume the honey produced in the study area. The first one is local consumers those who buy crude or processed honey directly from producers, retailers shop and processers consume the honey produced in the study area. They also includes local communities those who consume 'tej' and 'birz'. The main role of honey consumers in the study area was buying and consuming. The second type of consumer is global consumers those who buy exported honey consume it out of the country. As producers are benefited when they sell their products in bulk to wholesalers, local collectors or others.

\subsection{Honey Value Chain Map}

Different actors, supporters and services providers who involved in honey value chain were interviewed to illustrate their position and roles in milk value chain in the study district and its results were summarized and presented in the following milk chain maps.

\subsection{Honey Production}

In the study area beekeepers have good indigenous knowledge of traditional beekeeping and an important agricultural practice with mixed farming systems. Beekeeping was mostly traditional and in some extent there is performing of modern beekeeping practice. There are three types of beehives used for honey production. These are traditional, transitional and modern beehives.

\subsubsection{Type of Beehive Used and Productivity of Beehive}

In the case of productivity of hives in the study area, honey yield was markedly different for the types of beehives used. Based on the study result, the average yield per year of a traditional hive used in the district was $5.4 \mathrm{~kg}$, whereas the average yield per year of transitional hive was $13.6 \mathrm{~kg}$ and modern beehive $22.4 \mathrm{~kg}$. The result also shows that the average market supply of honey per households were $168.43 \mathrm{~kg}, 58.61 \mathrm{~kg}$ and $108.620 \mathrm{~kg}$ those households who used traditional, transitional and improved beehives, respectively in the study area.

Table 4. Volume of annual honey production and market supply.

\begin{tabular}{lllll}
\hline \multirow{2}{*}{ Description } & \multicolumn{4}{l}{ Type of hive used } \\
\cline { 3 - 5 } & & Traditional & Transitional & Modern \\
\hline Annually honey & Mean & 5.4 & 13.6 & 22.4 \\
yield/hives (kg) & SD & 1.70 & 1.25 & 0.12 \\
Annually honey & Mean & 176.42 & 89.73 & 114.56 \\
yield/households (kg) & SD & 3.4 & 8.26 & 14.13 \\
Volume supplied to & Mean & 168.43 & 58.61 & 108.6 \\
market (kg) & SD & 12.58 & 32.07 & 11.21 \\
\hline
\end{tabular}

\subsubsection{Activity Calendar for Beekeepers of Negele Arsi}

In the study district the activities performed and their respecting time presented as follow:

Table 5. Honey production activity calendar in Negele Arsi district.

\begin{tabular}{|c|c|c|c|c|c|c|c|c|c|c|c|c|}
\hline \multirow{2}{*}{ Activity } & \multicolumn{12}{|c|}{ Months in a year } \\
\hline & Sept & Oct & Nov & Dec & Jan & Feb & Mar & Apr & May & Jun & July & Aug \\
\hline \multicolumn{13}{|l|}{$\begin{array}{l}\text { Hive preparation and } \\
\text { Management practices }\end{array}$} \\
\hline \multicolumn{13}{|l|}{ Honey harvest } \\
\hline \multicolumn{13}{|l|}{ Marketing } \\
\hline \multicolumn{13}{|l|}{ Colonies swarming } \\
\hline Colonies absconding & & & & & & & & & & & & \\
\hline
\end{tabular}

Source: [9]

\subsection{Constraints and Opportunities of Chain Operators}

To utilize the existing potential of beekeeping sub sector, identifying the existing challenges and opportunities of honey production are paramount importance. Several factors have contributed to keep honey production from reaching its 
full market potential.

FUNCTIONS
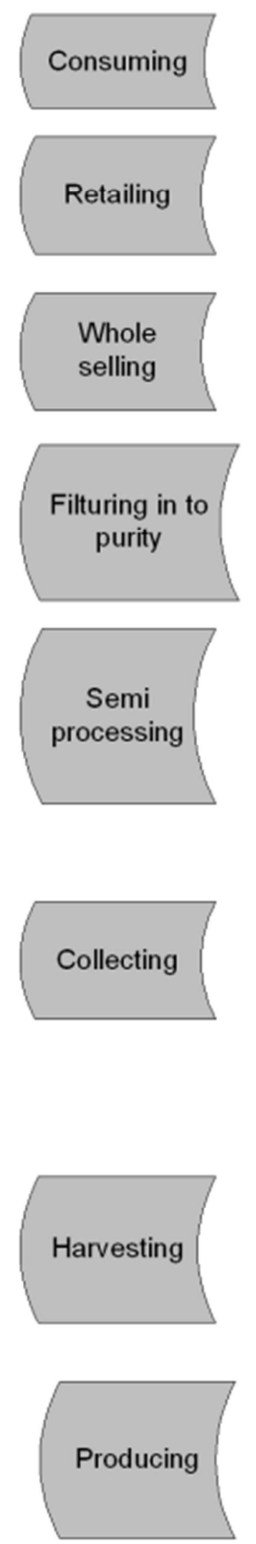

Input suppling
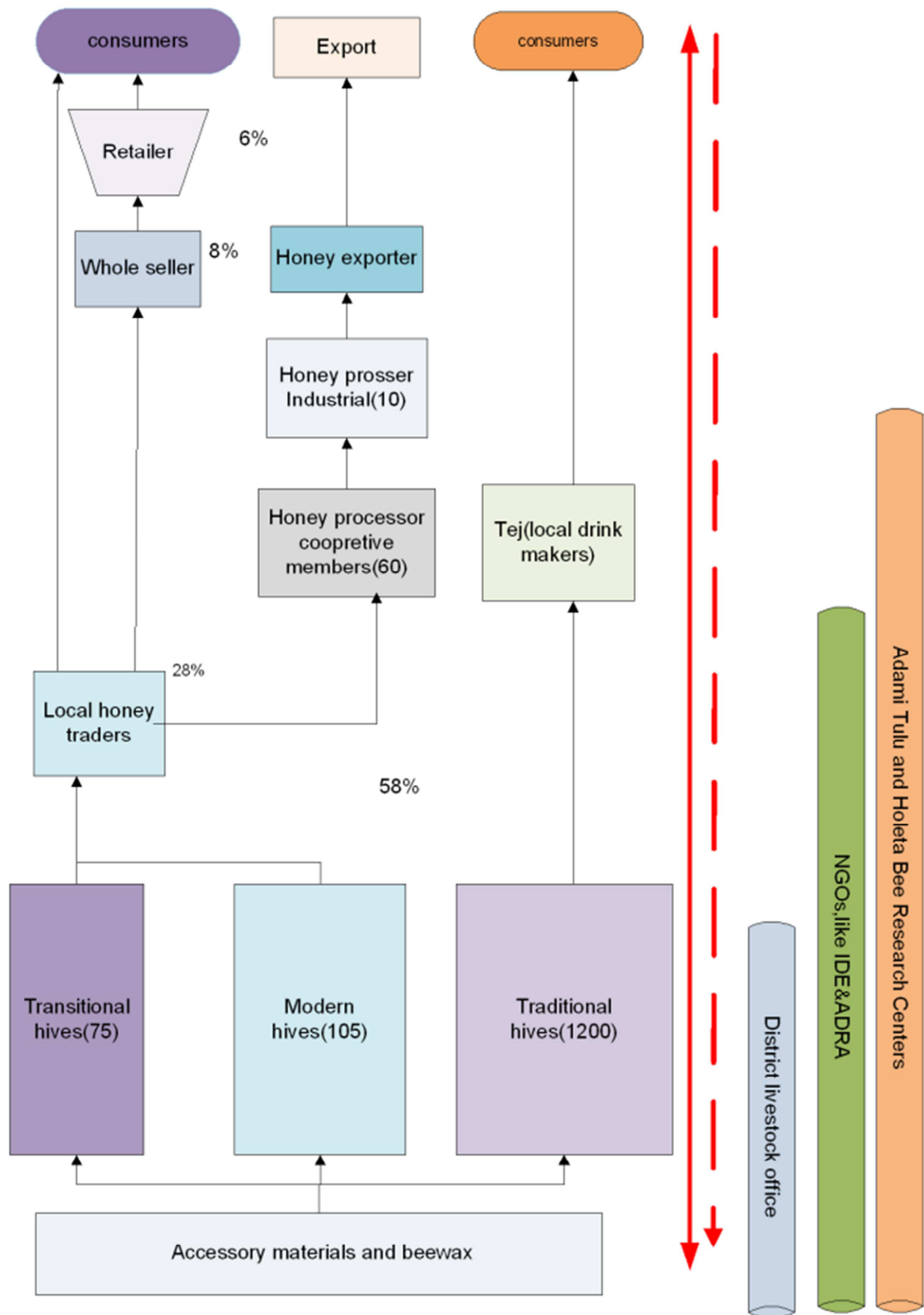

Figure 1. Honey value chain map of Smallholder Beekeepers in Negele Arsi district.

Key: Flow direction of information among actors

$----\rightarrow$ Flow direction of money

\subsubsection{Inaccessibility to Beekeeping Equipments}

Inaccessibility to modern bee equipment has contributed immensely to the low levels of production. An introduction of improved beekeeping technologies to the rural communities are beyond the purchasing power of the farmers and not easily available for those who can afford it. Most of the local beekeepers lack the basic tool that would be needed for private work like protective cloth, smoker, casting mould 
and honey extractors the study area.

\subsubsection{Inadequate of Beekeeping Knowledge and Skill}

Majority of the beekeepers lack the knowledge of appropriate methods of beekeeping. The low level of farmer's knowledge about modern beekeeping and low understanding about the use of modern beekeeping equipments caused improper use of the limited number of disseminated technologies. During the field study, many problems particularly on hive management were observed due to lack of skills and knowledge of modern hive. Some of the problems observed were: lack of sanitation around the hives; some of the hives were not placed on proper stand and lack of shade to protect bee colonies from temperature fluctuation.

\subsubsection{Shortage of Bee Forage}

Deforestation and the extinction of some high nectar and pollen sources of bee forage spices due to population pressure, lack of land use policy and the high demand for farmlands put pressures on mountainous areas to be used for crop production and livestock grazing. Moreover, burning of bushes and destroying of forestland for expansion of farmland result in elimination of good nectar and pollen producing tree species particularly during the long dry season.

\subsubsection{Prevalence of Honeybee Pests and Predators}

Honeybee pests and predators threaten the area and cause high mortality rates and severe economic loss. Pests and predators like ants, wax moth (Galleria mellonella), honey badger (Mellivoracapensis), small hive beetles (Aethinatumida), spiders, bee-eater birds, lizards, snake and bee lice (Braulacoecal) are the most commonly known enemies that attacking bees and destroying the bee hive in the area.

\subsubsection{Lack of Organized Marketing Channel}

It has been observed that in the study district marketing system of honey has many problems. Most of the center markets are far away from the producers and are inaccessible. Beekeepers travel on foot for several hours to sell their honey. The lack of grading systems does not encourage farmers to produce high quality products, thus, the price of honey changes widely based on the good will of buyers.

\subsubsection{Pesticides Poisoning}

Farmers in Negele Arsi practice mixed farming system. The cereal is an important component of mixed farming system. To control weeds in crop (wheat, barley, maize and teff) farmers use pesticides. The indiscriminate chemicals used for crop protection are the main pesticides results in killing the bees as well as the contamination of hive products. The problem becomes more severe because of unsystematic utilization of these chemical and the type and time of application. As it was seen from the beekeeper point of view, poisoning of honeybees by agrochemical has been increased from time to time. Some beekeepers lost totally their colonies due to agrochemical. The current study result was in line with $[14,3,11]$ who reported that lack of bee forage, honeybee pests and predators and agro-chemicals are the major constraints of beekeeping in all regions of Ethiopia while the level of rank are varied from place to place.

\subsubsection{Colony Absconding and Migration}

Colony absconding and migration is the main challenge of beekeepers in the study area. The respondents indicated that the reasons for colony absconding were shortage of forage pests and predators, poor harvesting methods, poor sanitation control, bad weather condition and diseases.

\subsubsection{Shortage of Bee Colony}

The majority of the beekeepers interviewed responded that one methods of obtaining bees is by capturing a wild colony during the reproductive swarming season. However, wild bees habitats are increasingly being destroyed as a result of expansion of farmland and agrochemical application are often suffered from total destruction of their nest. Responded also added that colony shortage is main challenges to start bee farms and expand the existing bee farm.

\subsubsection{Lack of Adequate Extension Services}

Lack of adequate extension services was also another beekeeping constraint identified in the study area. Except for dissemination of some modern hives and few beekeeping equipments, the farmers did not receive any technical and financial assistance to improve their productivity.

\subsection{Opportunities of Chain Operators}

Despite these constraints in the study area, there are also opportunities such as availability of area closures, high demand for honey and its by-products at national, regional and international market, existence of different governmental and nongovernmental organizations that working on beekeeping sub-sector, presence of good government policy, presence of farmers having indigenous knowledge and skills who are motivated to adopt improved technologies and existence of reforestation program are some of the opportunities for honey production and marketing by most of the producers.

\subsection{Analysis of Honey Production Constraints with Causal Diagram}

The following causal diagram is showing the constraints of beekeeping in the study area.

\subsubsection{PEST Analysis of Honey Production and Marketing Constraints in Negele Arsi District}

PEST stands for the Political, Economical, Social and Technological analysis tool is used to describe the general environment in Negele Arsi district and its impact on beekeeping development. 


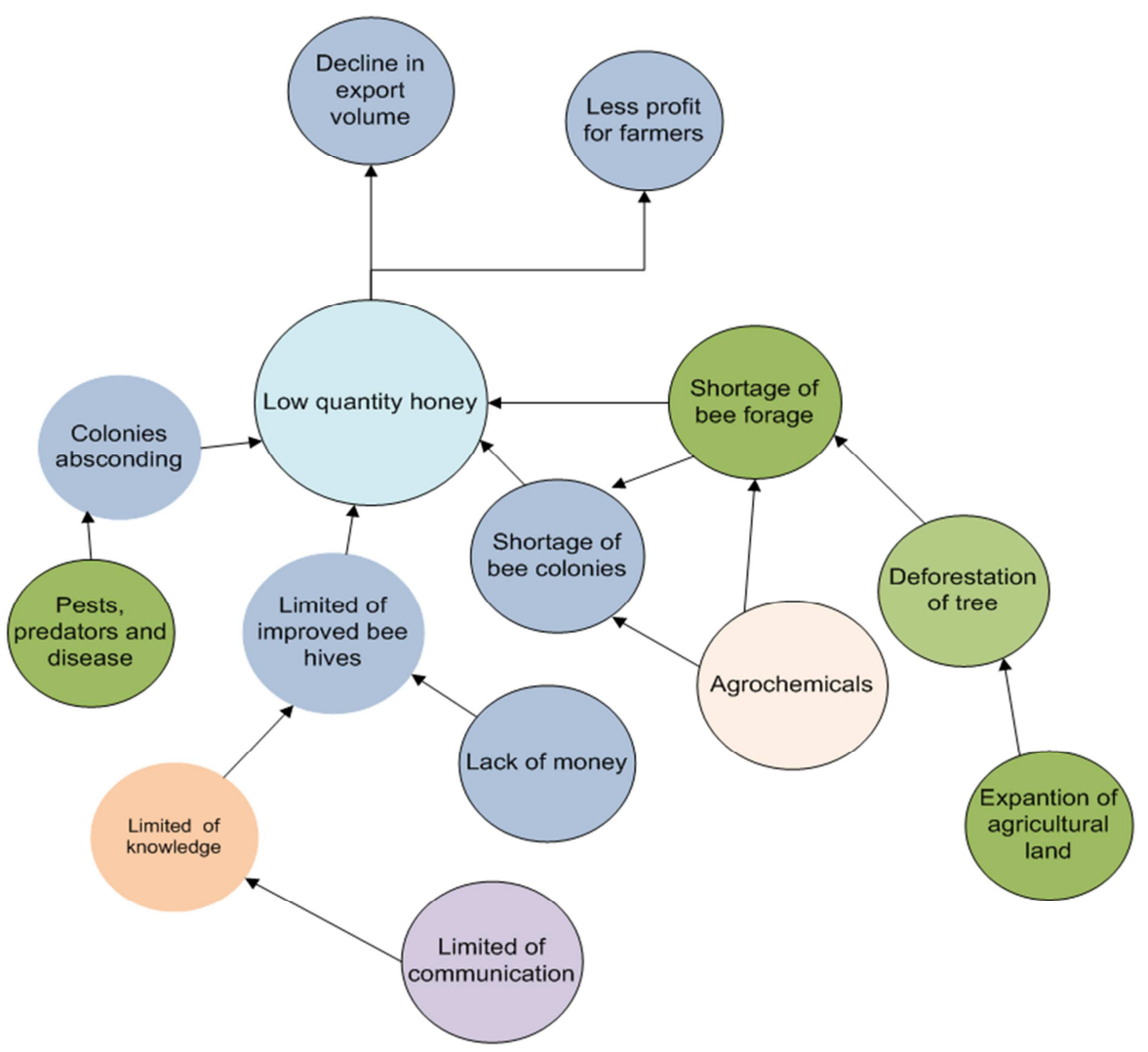

Figure 2. Causal diagram of beekeeping constraints.

Table 6. PEST Analysis of Beekeeping in Negele Arsi district

\begin{tabular}{ll}
\hline Political & Economical \\
1. Lack of extension services & 1. Low profitability of beekeepers \\
2. Priority is given for crop production rather than livestock production & 2. Low bee products and quality \\
3. Lack of credit access for beekeepers & 3. High costs of beekeeping equipments \\
4. Insufficient research and training institutions & 4. Colony absconding and migration \\
5. Shortage of trained man power & 5. Low honey price \\
6. Poor infrastructures & 6. Market problems \\
Technological & Social \\
$\begin{array}{ll}\text { 1. Shortage of beekeeping equipments } & \text { 1. The value placed up on honey for use at ceremonies and festival not as } \\
\text { 2. Increase use of agro-chemicals } & \text { regular income } \\
\text { 3. High costs of beekeeping materials } & \text { 2. Consumers preference may depend on color of honey } \\
\text { 4. Lack of market information } & \text { 3. Low income groups demand for cheaper and unprocessed honey } \\
\text { 5. Limited of communication } & \end{array}$ \\
\hline
\end{tabular}

\subsubsection{SWOT Analysis of Beekeeping in Negele Arsi district}

The strength, weakness, opportunities, and threat involved in input supply, production, processing and trading of honeybee products are discussed (Table 7).

Table 7. SWOT analysis of smallhonder beekeepers in the Negele Arsi districts.

\begin{tabular}{ll}
\hline Strengths & Weaknesses \\
& 1. High cost of modern beehive and accessories \\
1. Indigenous knowledge of beekeepers on beekeeping & 2. Poor harvesting techniques \\
2. Requires limited resources and is suitable for rural people & 3. Dominancy of traditional hive \\
3. Presence of high interest in beekeeping & 4. Limited knowledge and skills of beekeeping \\
4. Alternative income option to household without land & 5. Lack of credit services \\
5. Solution to poverty eradication & 6. Adulteration of honey \\
6. Potential for organic honey & 7. Lack of awareness on honey quality \\
7. Cheap to start & 8. Poor handling of honey \\
8. Contribute to environmental conservation & 9. Inadequate value addition skills and facilities \\
9. Sectoral support from local and national NGOs like SNV and IDE & 10. Inadequate market information \\
& 11. Low product prices for producers \\
\hline
\end{tabular}




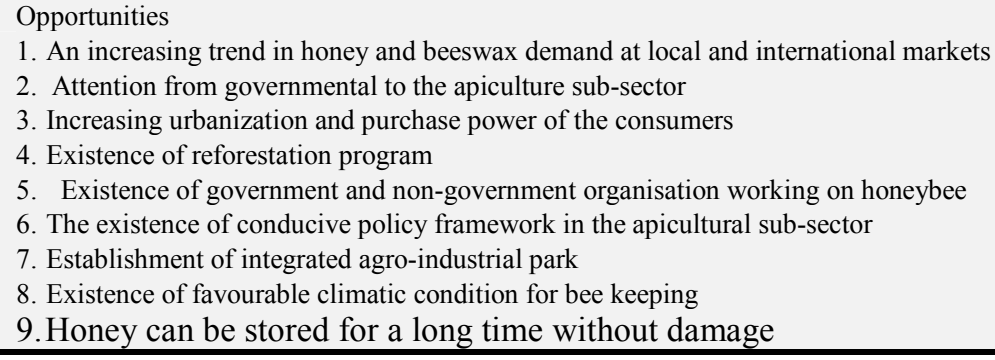

1. An increasing trend in honey and beeswax demand at local and international markets

2. Attention from governmental to the apiculture sub-sector

3. Increasing urbanization and purchase power of the consumers

4. Existence of reforestation program

5. Existence of government and non-government organisation working on honeybee

6. The existence of conducive policy framework in the apicultural sub-sector

7. Establishment of integrated agro-industrial park

8. Existence of favourable climatic condition for bee keeping

9. Honey can be stored for a long time without damage

\subsection{Identified Honey Marketing Channel}

The main honey market channels in the district have been identified to be six, and honey follows the six main routes from the point of its production to its consumption. Producers, local honey collectors, wholesalers, retailers, processors, tej houses and consumers were identified as the market chain actors in the study area. Beekeepers are the first actors who are accountable for honey production. The beekeepers harvest honey and sell mostly to consumers, retailers, local honey collectors, wholesalers, tej makers, processors and consumers. The estimated total amount of honey produced from sampled households by the year of 2016 was $8,432 \mathrm{~kg}$, of which $35.5 \%$ of its share was carried out by channel VI. Similarly, channel I and channel IV took the second and third largest share of honey flow accounting for $16.3 \%$ and $15.4 \%$, respectively. Therefore, channels VI and I together accounts for about $51.8 \%$ of the total honey flow, and this indicates that the flow of honey market in the study area is concentrated on these channels. It can also be said that channels VI and I are the most advantageous honey market channels for honey producers.

Channel I Producers 5 Consumers $=1374.4 \mathrm{~kg}(16.3 \%)$

Channel II Producers $\Rightarrow$ Honey collectors' $\overrightarrow{ }$ Consumers $=1239.5 \mathrm{~kg}(14.7 \%)$
Threats
1. Deforestation can lead to loss of habitat for bees
2. Loss of bees from pesticide use
3. Presence of pests and predators that attack beekeeping
4. Increasing the costs of beekeeping equipments and tools
5. Widely usage of agro chemicals in the district
6. Drought/rain-failure
7. Declining of bee colony
8. Risk of quality consistency problems

Channel III Producer $\Rightarrow$ Retailers' $\Rightarrow$ Consumers $=1028.7 \mathrm{~kg}(12.2 \%)$

Channel IV Producers' $\Rightarrow$ Wholesalers $\Rightarrow>$ 'Retailers $\Rightarrow$ Consumers $=1298.5 \mathrm{~kg}(15.4 \%)$

Channel V Producers' $\Rightarrow$ Tej makers $\Rightarrow$ Consumers $=497.5 \mathrm{~kg}(5.9 \%)$

Channel VI Producerss $\Rightarrow$ Collectors' $\Rightarrow$ Wholesalers' $\Rightarrow$ Retailers' $\Rightarrow$ Consumers $=2993 \mathrm{~kg}(35.5 \%)$

\subsection{Marketing Cost and Marketing Margin of Honey Marketing}

Marketing cost and marketing margin of honey marketing. In the study area, the producers did not incurred any marketing cost when they sale raw honey to consumers directly but they incurred some marketing cost when they sale to marketers. Major marketing cost includes the honey transportation cost, cost of the container if not returned by marketers, cost of packing in case of packed honey, labor charge in honey loading and unloading. Overall marketing cost of wholesalers, processors, local collectors and retailers to the final consumer in the study area was Ethiopian birr. 85 $\mathrm{kg}-1$, Ethiopian birr. $105 \mathrm{~kg}-1$, Ethiopian birr. $48 \mathrm{~kg}-1$ and Ethiopian birr. $75 \mathrm{~kg}-1$ respectively (Table 8).

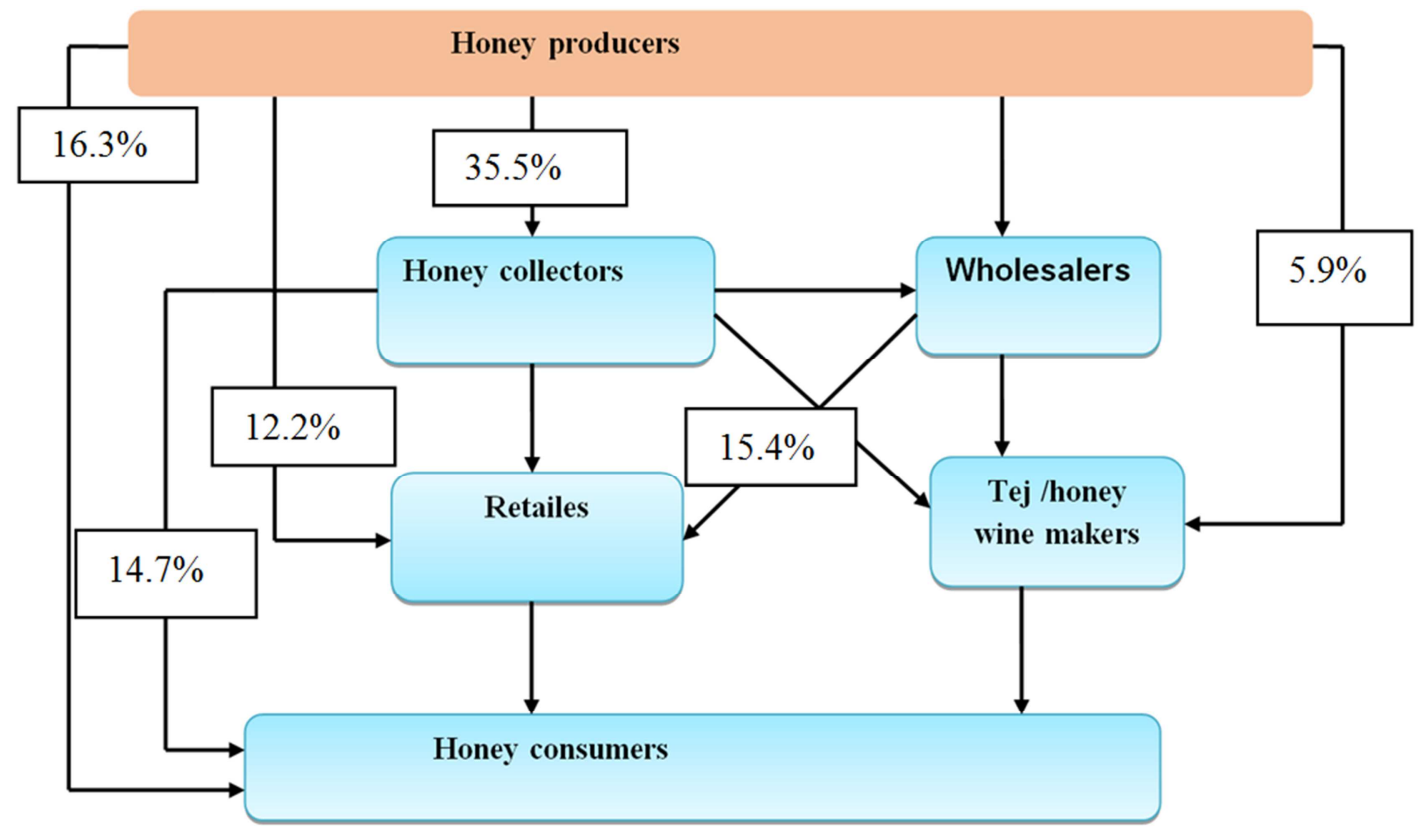

Figure 3. Honey marketing channel of the study area. 
Table 8. Marketing cost and margin of different intermediaries.

\begin{tabular}{llllll}
\hline Marketing Intermediaries & Purchase price & Marketing Cost & Selling price & Marketing margin & $\%$ \\
\hline Wholesalers & 210 & 55 & 350 & 85 & $24.3 \%$ \\
Processors & 210 & 65 & 380 & 105 & $27.6 \%$ \\
Collectors & 210 & 32 & 300 & 48 & $16.00 \%$ \\
Retailers & 240 & 350 & 75 & $21.4 \%$ \\
\hline
\end{tabular}

\subsection{Sources of Market Information}

There is information flow in both directions from producers to consumers and from consumers to producers. The findings of this study revealed that producers obtained information on production and beekeeping practices from various sources. About half (52.2\%) indicated government as their major source of information on honey which is followed colleague farmers (19.6\%) and middleman (13\%). According to [9], there was no recorded data on beekeeping activities like information on the location of beekeepers, volume of honey produce, the frequency of harvest and price of honey.

Table 9. Sources of market information.

\begin{tabular}{lll}
\hline Sources of information & Respondents & Percent \\
\hline Government & 20 & 55.6 \\
Middleman & 4 & 11.1 \\
Farmers & 6 & 16.7 \\
Combination of the above & 5 & 13.9 \\
Other & 1 & 2.8 \\
Total & 36 & 100 \\
\hline
\end{tabular}

\subsection{Factors Affecting Honey Selling Pricing the Study} Area

\subsubsection{Color of Honey}

The appearance of honey by itself is determined by its color. Color gives rough information about dirt content and the season of production. It becomes determinant of price if and only if it is accompanied by good taste. The color of honey is different depending on the season of production in Negele Arsi district. The flowering season of different flowering plants is in a different seasons. Depending on their color there are two types of honey; the honey with white color and the honey with red color. These honeys with different colors are harvested in different seasons. In the study area, most beekeepers are harvesting honey two times per year in January and May. The honey harvested in May is white in color while the honey which is harvested in January is red in color. White honey is the most preferable honey by the buyers, due to its good taste, attractive aroma. It is fetch high price for beekeepers. Red honey is not preferred like that of white honey.

\subsubsection{Product Availability}

As the price of a good goes up, consumers demand less of it and more supply enters the market. If the price is too high, the supply will be greater than demand, and producers will be stuck with the excess. Conversely, as the price of a good goes down, consumers demand more of it and less supply enters the market. If the price is too low, demand will exceed supply, and some consumers will be unable to obtain as much as they would like at that price.

\subsubsection{Holding Containers}

Beekeepers were used unclean collecting material during harvesting and after harvesting for storage or for marketing, which contaminate the honey. Traditionally beekeepers were using clay pots, plastic containers, the sack prepared from the skin of animals, tin, and a plastic sack prepared for honey collecting and sack of urea fertilizer which has a chemical content that can spoil the quality of the honey. These materials are poor in quality and they are not hygienic.

\subsubsection{Honey Qualities}

The price of the honey in the local market is different depending on the quality of the honey. The result of this study indicates that, the majority of buyers determine the price of the honey depending on the quality of beekeepers honey. This result is supported by finding of [12] which reported that the quality of honey (color, taste, dirty and wax content and odor) is used for pricing of honey and the high quality honey is offered a high price. The study result reveals that smallholders honey quality in the study area is affected by different factors. Excess using of smoking materials, handling problem during marketing, harvesting of un ripened honey and mixing of high quality honey with low quality honey are the main problems that reduce the quality of the smallholder farmers' honey.

\subsubsection{Market Access}

The market access has been explained in terms of market place distance, traders' proximity, transaction time and transportation access and its affordability. It has been observed that in the study area the marketing system of honey has many problems. Most of the local markets are far away from the beekeepers and are inaccessible. They travel on foot for several hours to sell their honey. Since smallholder lack money to pay for transportation cost and usually come on foot, they are suffering from frequent travel to market for the same product since they miss the time of honey selling for rural markets are active and hot within specific hours. This is because traders looking for high quantity of honey in a specific time.

\subsubsection{Seasonality of Supply}

According to the information from survey, the price of honey is high in the dry seasons and during wedding time, holiday, cultural ceremonies and when there was no honey harvesting (June to August). On the other hand, honey price goes down during harvesting period from November to December and in May in the study area 
Table 10. Factors affecting honey selling price in the study area.

\begin{tabular}{llll}
\hline Parameter & Frequency & Percentage (\%) & Rank \\
\hline Honey quality & 20 & 32.3 & $1^{\text {st }}$ \\
Seasonality of supply & 13 & 21 & $2^{\text {nd }}$ \\
Color of honey & 11 & 17.7 & $3^{\text {rd }}$ \\
Product availability & 8 & 12.9 & $4^{\text {th }}$ \\
Market access & 6 & 9.7 & $5^{\text {th }}$ \\
Holding containers & 4 & 6.5 & $6^{\text {th }}$ \\
\hline
\end{tabular}

\section{Conclusion}

The study result showed that, the major value chain actors in the study district were producers, local collectors, wholesalers, retailers, local drink makers and final consumers of the product were the main chain actors, while Negele Arsi livestock development and fisher resource office, Adami Tulu Agricultural Research Center, IDE and SNV Ethiopia were the main chain supporters and service providers. The marketing margin of processors $(27.6 \%)$ was found to be highest, followed by wholesalers $(24.3 \%)$ based on their selling price. The major constraints of honey production and marketing system identified in the study district were inaccessibility to beekeeping equipments, inadequate of beekeeping knowledge and skills, shortage of bee forage, prevalence of honeybee pests and predators, lack of organized market channel, pesticides poisoning, lack of adequate extension services, honeybee colony absconding and migration and shortage of honeybee colony. Despite these, there are also opportunities such as availability of area closures, high demand for honey at national, regional and international market, existence of different governmental and nongovernmental organizations that support beekeeping sub-sector, existence of good governmental policy, existence of farmers with indigenous knowledge and skills who are interested to accept improved technologies, existence of reforestation plan and existence of different flowering plants are some of the opportunities for honey production and marketing by most of the producers. Most beekeepers and local honey traders of Negele Arsi area faced lack of adequate financial support to invest on improved honey production technologies, storage, processing facilities and packaging. Therefore, efforts should be geared towards capacity building through training, access to modern beekeeping technologies, improving extension service, access to credit and market information and establishment of beekeepers cooperatives are recommended to improve honey value chain in the study area.

\section{Conflict of Interests}

All the authors do not have any possible conflicts of interest.

\section{Acknowledgements}

Authors are expressing their heartfelt and deep gratitude to Negele Arsi livestock development and fisher resources office, local honey traders, whole sellers, retailers, consumers, beekeepers and the development agents for their willingness to be interviewed and for giving us all necessary information.

\section{References}

[1] District's Office of Agriculture and Rural Development (OoARD, 20010. Negele Arsi, Ethiopia.

[2] FAO 2010, FAOSTAT database on Agriculture and Nutrition. Food and Agricultural Organization of the United Nations, Rome, Italy. Available at: http://globaldirectory.paris21.org/Multilaterals/FAO [accessed on $08 / 08 / 2014]$.

[3] Gebretsadik Teklu, and Negas Dinku. 2016. "Honeybee production system, challenges and opportunities in selected districts of Gedeo Zone, Southern Nation, Nationalities and Peoples Regional State, Ethiopia international journal of research, 4: 49-63.

[4] Gemechis, L. (2015). Honey Production and Marketing in Ethiopian. American Journal of Life Sciences. Vol. 3, No. 1, pp. 42-46. doi: 10.11648/j.ajls.20150301.18

[5] Jony, G., 2011. Impact of Contract Farming On Household Income of Smallholder Farmers, The Case Of Organic Honey Production In South West Ethiopia, Sheka Zone. Wageningen University. Available at: <http://edepot.wur.nl/193737> [accessed on 09/07/2014].

[6] MoARD (2007). Livestock Development Master Plan Study: Data Collection and Analysis. Phase I Report, Volume N, Apiculture. MoARD, Addis Ababa, Ethiopia.

[7] MoARD (Ministry of Agriculture and Rural Development), 2009. Addis Ababa, Ethiopia.

[8] MoA and ILRI. 2013. Apiculture value chain vision and strategy for Ethiopia. Addis Ababa, Ethiopia Ministry of Agriculture and International Livestock Research Institute.

[9] Own Unpublished PRA survey, 2016. Study of the profitability of beekeeping and marketing access in West Arsi Zone and East.

[10] Oxfam. (2011). Engaging Smallholders in Value Chains: Creating New Opportunities for Beekeepers in Ethiopia.

[11] Seyoum Elifyos and Anja Abera. 2018. Assessment of beekeeping production system and constraints in basketo special woreda, Southern Ethiopia. Horticulture International Journal, 2 (3): 124-127.

[12] Samuel Karafo, L. 2010. Factors affecting honey pricing in domestic supply chain the case of Konso district, Ethiopia. Available at: < http://edepot.wur.nl/166148> [accessed on 21/06/2014].

[13] Shenkute, A. G., Yemisrach Getachew, Y., Assefa, D., Nuru Adgaba, N., Ganga, G. and Bonga, W. A. 2012. Honey production systems (Apismellifera L.) in Kafa, Sheka and Bench Maji zones of Ethiopia., Agricultural Research Center, Ethiopia., Bonga Agricultural Research Center, Ethiopia., King Saud University, Riyadh, Saudi Arabia., Southern Agricultural Research Institute, Ethiopia., Ambo University, Ambo, Ethiopia. Available at: $<$ http://www.academicjournals.org/article/article1400142729_ Shenkute\%20et\%20al.pdf $>$ [accessed on 03/07/2014]. 
[14] TayeBeyene (2014). Assessment of the performance of wonchi beekeepers' association: a case of wonchi district, south west shoa zone of Oromia, Ethiopia. 2: 2. 